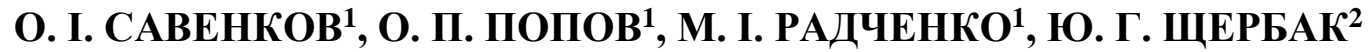 \\ ${ }^{1}$ Національний університет кораблебудування ім. адм. Макарова, Україна \\ 2 Чорноморський Національний університет ім. П. Могили, Украӥна
}

\section{ПІДВИЩЕННЯ НАДІЙНОСТІ СУДНОВИХ ЕНЕРГЕТИЧНИХ УСТАНОВОК ШЛЯХОМ УСУНЕННЯ НЕГАТИВНОГО ВПЛИВУ РОЗЦЕНТРОВОК ОСЕЙ З'СДНУВАЛЬНИХ ВАЛІВ}

\begin{abstract}
Досліджено вплив на працездатність і надійність суднових енергетичних установок перекосів осей з'єднувальних валів суднових агрегатів. Розглянуто причини виникнення розцентровок осей з'єднувальних валів суднових агрегатів $і$ запропоновано їх класифікацію. Відмови суднових енергетичних установок класифіковано по їх впливу на працездатність установки (по наслідкам), по способам їх усунення $i$ по характеру та поділено на групи у відповідності до класів. Показано, щзо у процесі експлуатації, в умовах перекосу осей, традиційні конструкиії зубчастих муфт, характеризуються нерівномірним розподілом зусиль між спряженими парами зубів, щэо призводить до їх перевантаження $i$, як наслідок, зниження навантажувальної здатності, зростання величин контактних напружень, погіршення умов змащення поверхонь тертя зубів, збільшення витрат потужності на тертя, зниження коефіцієнту корисної дії та погіршення віброакустичних характеристик внаслідок ударного навантаження зубів. Розглянуто способи підвищення ефективності роботи суднових енергетичних установок шляхом забезпечення параметрів надійності головних енергетичних установок за рахунок усунення негативного впливу розиентровок осей з'єднувальних валів суднових агрегатів иляхом застосування компенсуючих пристроїв. Запропоновано використовувати у якості компенсуючих пристроїв конструкиії зубчастих муфт підвищеної експлуатаційної ефективності, котрі, в умовах перекосу осей, характеризуються більш рівномірним розподілом зусиль між усіма спряженими парами зубів ніж існуючі, тобто працюють, практично як ідеальний шарнір. Стосовно зубчастих муфт, шчо пропонується, встановлено раніме невідому об'єктивно існуючу властивість зубчастої муфти, прачюючої при перекосах осей з'єднувальних валів, яка полягає в тому, щзо при певному нелінійному законі зміни твірних бічних поверхонь зовнішніх зубів втулки зусилля в процесі навантаження муфти розподіляються рівномірно між всіма спряженими парами зубів. Розглянуто застосування зубчастих муфт підвищеної експлуатаційної ефективності у складі суднових енергетичних установках та складено відповідно принципову $і$ функціональну (структурну) схеми головного суднового агрегату з послідовним з'єднанням елементів 3 метою оцінки впливу на параметри надійності.
\end{abstract}

Ключові слова: суднова енергетична установка; надійність; розиентровка осей; перекіс осей; судновий агрегат; зубчаста муфта.

\section{1. Аналіз проблеми і постановка мети дослідження}

Аналіз літературних джерел, вказує на те, що однією з проблем, що неминуче виникає в процесі експлуатації суден, є втрата ефективної потужності, викликана перекосами осей з'єднувальних валів суднових агрегатів, при їі передачі від двигуна судновому валопроводу, через з'єднувальний вузол «муфта-вал-муфта», котрі негативно впливають на працездатність і надійність головних енергетичних установок (ГЕУ) [1-3].

Аналіз експлуатаційних характеристик і техніко-економічних показників суден вказує на те, що під час експлуатації перекоси осей з'єднувальних валів суднових агрегатів, виражених у вигляді зсу- вів та зламів, збільшуються і перевищують встановлені норми центровки, що призводить до втрати ефективної потужності, при ії передачі від головного двигуна судновому валопроводу, через сполучний вузол «муфта-вал-муфта» $[2,3]$.

Загалом, перевищення вказаних норм, призводить до погіршення показників безвідмовності, довговічності та ремонтної придатності головних суднових агрегатів, та може призводити до позапланових зупинок енергетичних установок на ремонт, внаслідок чого знижується безвідмовність експлуатації судна, підвищується вірогідність виникнення аварійних ситуацій та збільшуються витрати на ремонт.

Мета дослідження - забезпечення параметрів надійності суднових енергетичних установок шля- 
хом усунення негативного впливу розцентровок осей з'єднувальних валів суднових агрегатів застосуванням компенсуючих пристроїв

\section{2. Результати дослідження}

Надійність суднових агрегатів забезпечується при їх виготовленні. Вона залежить від якості виготовлення складових їх деталей, методів поопераційного технологічного контролю, якості збірки механізмів і їх вузлів, методів випробування готової продукції та інших показників технологічного процесу. Рівень надійності, закладений при розробці і забезпечений виробництвом, в подальшому визначається умовами експлуатації суднових агрегатів, періодичністю технічного обслуговування і обсягу ремонтів та іншими експлуатаційними чинниками [2, 3]. До вказаних чинників, зокрема, відносяться i розцентровки осей з'єднувальних валів головних суднових агрегатів.

Розцентровка (перекоси) являє собою порушення співвісності валів, тобто відхилення від номінального розташування осей в будь-якому напрямі (рис. 1). Зазначені відхилення називаються зміщеннями і вони, в свою чергу, поділяються на поздовжні, радіальні, кутові та комбіновані. Слід зазначити, що кутові зміщення також називають зламами. Зміщення і злами осей перераховуються в кути перекосу осей, що не перевищують, згідно ДСТУ 2747-94 (раніше ГОСТ 5006-55) значення $\psi=8,7 \cdot 10-3$ рад, що еквівалентно $0,5^{\circ}$, таким чином, терміни «розцентровка осей» та «перекіс осей» $є$ адекватними [2].

Причини виникнення розцентровок осей в періоди експлуатації суден можливо класифікувати за рядом конструктивних, технологічних і експлуатаційних факторів (рис. 2).

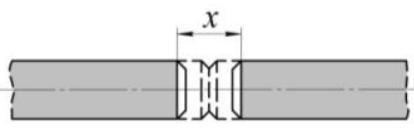

a)

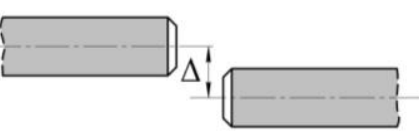

б)

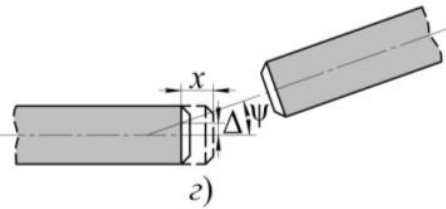

Рис. 1. Зміщення осей з'єднувальних валів суднових агрегатів: a - поздовжнє, б - радіальне, в - кутове (злам), г - комбіноване

ПРИЧИНИ ВИНИКНЕННЯ РОЗЦЕНТРОВОК ОСЕЙ З’ЕДНУВА/ЫНИХ ВА/ІВ СУДНОВИХ АГРЕГАТІВ

\begin{tabular}{|c|}
\hline ТЕХНО/ОПЧН \\
\hline 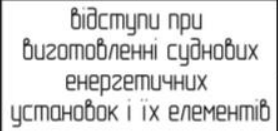 \\
\hline
\end{tabular}

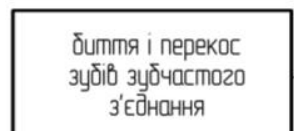
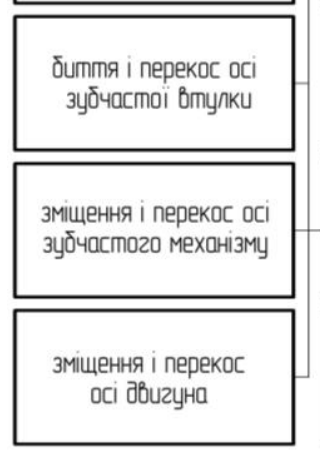

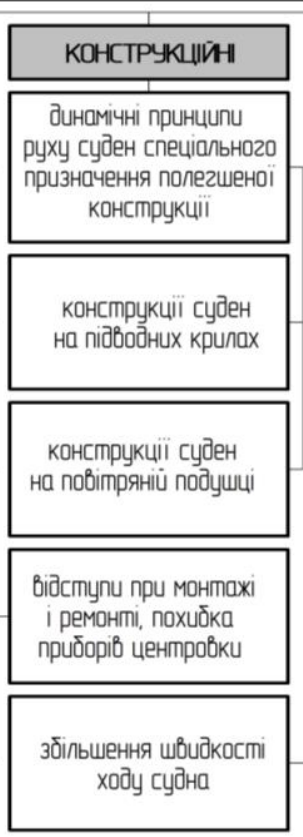

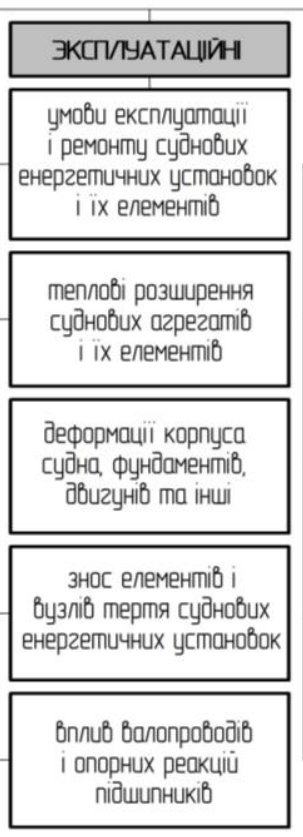

СाЕИЯфЧн

специфічні цмоВи експпуатаціiі суден

експлуцапація субен

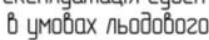
плаB̈ання

зіткнення і посаӚк суден на мілUну

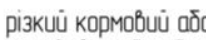

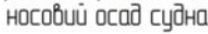

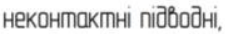

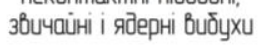

Рис. 2. Класифікація причин виникнення розцентровок осей з'єднувальних валів суднових агрегатів 
При розцентровках осей істотно перевантажується не тільки проміжний, але й вихідний та вхідний вали відповідно двигуна і редуктора, що в свою чергу негативно позначається на параметрах надійності суднових енергетичних установок та їх елементів, до яких відносяться безвідмовність, довговічність, ремонтопридатність та збереженість (рис. 3) [2].

3 перерахованих показників надійності (див. рис. 3) слід детально розглянути безвідмовність, яка являє собою властивість СЕУ безперервно зберігати працездатний стан протягом певного часу або певного напрацювання. У свою чергу, працездатний стан, це такий стан СЕУ, при якому значення всіх параметрів, що характеризують здатність виконува- ти задані функції, відповідають вимогам нормативно-технічної та (або) конструкторської документаціï.

Порушення працездатного стану СЕУ називають відмовою. Всі відмови СЕУ умовно підрозділяють на класи, які ділять на групи за загальними ознаками (рис. 4) [1-3].

Як видно 3 рис. 4 погіршення показників надійності СЕУ неминуче призводить до зниження ефективної роботи судна і може призводити до відмов суднового обладнання та позапланових зупинок на ремонт, що в свою чергу впливає на безвідмовність плавання судна і може призводити до збільшення ймовірності виникнення аварійних ситуацій i зростання витрат на ремонти.

\section{ПОКАЗНИКИ НАДІЙНОСТІ ЕНЕРГЕТИЧНИХ ЧСТАНОВОК I ЇХ Е/ЕМЕНТІВ}

\begin{tabular}{|c|}
\hline ðезВїідмовність \\
\hline 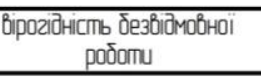 \\
\hline 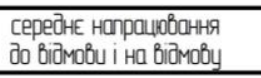 \\
\hline інтенсив̈ніспь Вї̈мов \\
\hline Iapamemp nomoky Bïмmoß \\
\hline
\end{tabular}
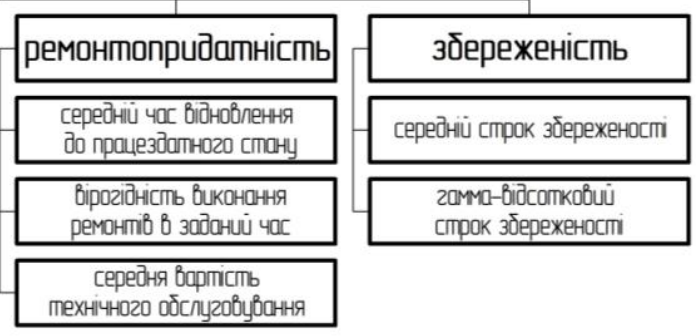

Рис. 3. Показники надійності енергетичних установок і їх елементів

\begin{tabular}{|c|c|c|}
\hline \multicolumn{3}{|c|}{ КЛАСИФІКАЦІЯ ВІДМОВ СУДНОВИХ ЕНЕРГЕТИЧНИХ ЧСТАНОВОК } \\
\hline $\mathrm{K} / \mathrm{AC} \mathrm{I}$ & K/AC ॥ & K/IAC III \\
\hline 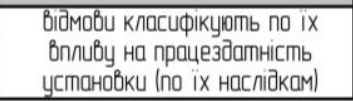 & 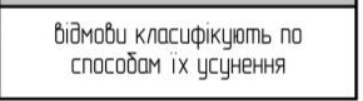 & 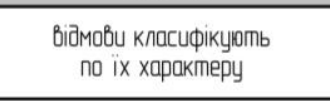 \\
\hline ГРУПА । & ГРУПА । & ГРУПА । \\
\hline 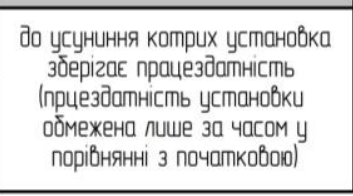 & 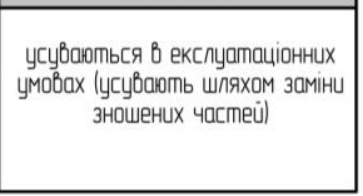 & 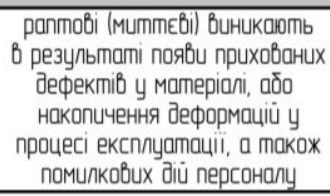 \\
\hline ГРУПА ॥ & ГРУПА ॥ & ГРУПА ॥ \\
\hline 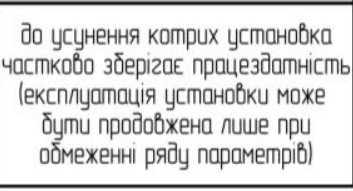 & 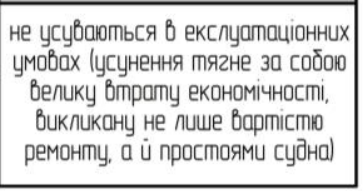 & 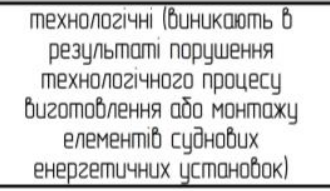 \\
\hline ГРУПА III & ГРУПА IV & ГРУПА III \\
\hline 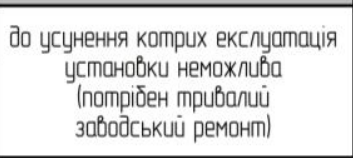 & 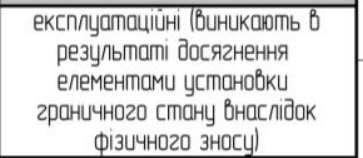 & 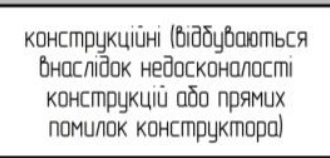 \\
\hline
\end{tabular}

Рис. 4. Класифікації відмов суднових енергетичних установок 
На теперішній час, питання усунення негативного впливу перекосів осей з'єднувальних валів суднових агрегатів на працездатність головних енергетичних установок здійснюється двома способами, або перецентровкою осей вказаних валів, що потребує зупинки судна та матеріальних витрат на ремонт, що в свою чергу призводить до втрати «провізної здатності судна», або застосуванням компенсуючих пристроїв, до яких зокрема відносяться зубчасті муфти. Однак, у процесі експлуатації, в умовах перекосу осей, традиційні конструкції зубчастих муфт, характеризуються нерівномірним розподілом зусиль між спряженими парами зубів, що призводить до їх перевантаження i, як наслідок, зниження навантажувальної здатності, зростання величин контактних напружень, погіршення умов змащення поверхонь тертя зубів, збільшення витрат потужності на тертя, зниження коефіцієнту корисної дії та погіршення віброакустичних характеристик внаслідок ударного навантаження зубів. Крім того, при перекосах осей з'єднувальних валів суднових агрегатів в зубчастих з'єднаннях виникають додаткові силові фактори у вигляді пружних згинальних моментів, які через вали передаються на опори, викликаючи в них додаткові навантаження, тим самим перевантажуючи опори механізмів, вхідні, вихідні та з'єднувані вали, шліцьові і болтові з'єднання, а також інші елементи силових агрегатів, тобто здійснюють на їх працездатність шкідливий вплив.

Забезпечення необхідного рівня надійності, як суднових енергетичних установок, так і елементів що входять до їх складу, є найважливішим завданням, так як виконання інших вимог при недостатній надійності втрачає будь-який сенс. Таким чином, для забезпечення виконання вимог надійності, в умовах розцентровок осей з'єднувальних валів, слід застосовувати вдосконалені або нові конструкції зубчастих муфт підвищеної експлуатаційної ефективності, котрі в умовах перекосу, характеризуються більш рівномірним розподілом зусиль між усіма спряженими парами зубів ніж існуючі і, як наслідок, забезпечують працездатність головних суднових агрегатів при передачі ефективної потужності [1-3].

Суднову енергетичну установку можна розглядати як систему, що складається 3 ряду окремих елементів, однак при оцінці надійності судна в цілому, яке є більш складною системою, СЕУ може розглядатися як окремий елемент, в зв'язку з чим ці поняття і визначення надійності справедливі як для складних систем, так і для окремих елементів (деталей, вузлів і агрегатів). Кількісно надійність агрегату залежить головним чином від трьох чинників: надійності елементів, що входять до складу головного суднового агрегату; характеру з'єднання елементів; тимчасових характеристик (час роботи еле- ментів на даному режимі). Тільки спільний розгляд всіх перерахованих факторів і їхнього впливу на інші характеристики агрегату дозволить визначити вимоги до надійності окремих елементів, а також найбільш раціональні заходи, спрямовані на ії підвищення. Для розрахунку надійності на підставі принципової схеми складається функціональна (структурна) схема агрегату, що відображає характер зв'язків елементів в його складі, з точки зору надійності здійснення робочого процесу (рис. 5).

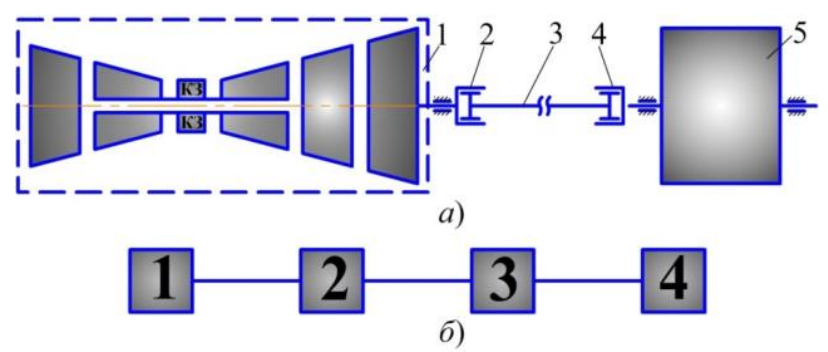

Рис. 5. Принципова схема головного суднового агрегату (а) : 1 - головний двигун; 2, 4 - зубчасті муфти; 3 - проміжний вал; 5 - редуктор, функціональна (структурна) схема головного суднового агрегату з послідовним з'єднанням елементів (б)

На рис. 5, а показана принципова схема головного суднового агрегату де всі елементи з'єднані послідовно, тобто функціональна схема являє собою послідовне з'єднання 3 чотирьох елементів (рис. 5, б). Відмова будь-якого 3 елементів призводить до відмови всієї послідовної системи. Зазначена система містить мінімально необхідну для здійснення робочого процесу число елементів (проміжний вал не враховується). У разі відмови будь-якого 3 елементів система не працює, елемент що відмовив відновлюється (ремонтується або замінюється).

Найбільш поширеною моделлю раптових відмов $є$ модель «випадкового викиду» параметра за встановлений рівень, яка підходить для будь-яких суднових механізмів, котрі завжди мають обмежену міцність, тобто $є$ деяке кінцеве граничне навантаження, яке він здатний витримати без відмови. 3 огляду на, що рівень гранично допустимого навантаження залишається постійними протягом всього часу експлуатації механізму і що, відмова виникає не внаслідок поступової зміни внутрішнього стану елементів механізму, а внаслідок перевищення граничного навантаження, доцільно використовувати експоненціальний (показовий) розподіл при порівняльній оцінці надійності головних суднових агрегатів та їх елементів при перекосах осей. Крім того, експоненціальний розподіл характеризується порівняною математичною простотою, а також тим, що в 
більшості випадків неминуча неточність розрахунку завжди йде в запас розподілу.

Безвідмовна робота послідовної системи за час $\mathrm{t} \epsilon$ подія, що полягає в справній роботі за зазначений час елементів системи 1, 2, 3 і 4 (рис. 5, б). Тоді в припущенні незалежності відмов елементів (таке припущення, як правило, робиться в теорії надійності) ймовірність безвідмовної роботи системи можна записати у вигляді

$$
P(t)=P_{1}(t) \cdot P_{2}(t) \cdot P_{3}(t) \cdot P_{4}(t)
$$

де $\mathrm{P}_{1}(\mathrm{t}), \mathrm{P}_{2}(\mathrm{t}), \mathrm{P}_{3}(\mathrm{t}), \mathrm{P}_{4}(\mathrm{t})$ - ймовірність безвідмовної роботи елементів 1, 2, 3 і 4 відповідно.

Ймовірність відмови

$$
\mathrm{Q}(\mathrm{t})=1-\mathrm{P}(\mathrm{t})=1-\mathrm{P}_{1}(\mathrm{t}) \cdot \mathrm{P}_{2}(\mathrm{t}) \cdot \mathrm{P}_{3}(\mathrm{t}) \cdot \mathrm{P}_{4}(\mathrm{t})
$$

Інтенсивність відмов

$$
\lambda(\mathrm{t})=\mathrm{f}(\mathrm{t}) / \mathrm{P}(\mathrm{t})=\lambda_{1}(\mathrm{t})+\lambda_{2}(\mathrm{t})+\lambda_{3}(\mathrm{t})+\lambda_{4}(\mathrm{t}),
$$

де $\mathrm{f}(\mathrm{t})$ - частота відмов (щільність розподілу напрацювання до відмови).

Середня напрацювання до відмови

$$
\mathrm{T}=\int_{0}^{\infty} \mathrm{P}_{1}(\mathrm{t}) \mathrm{P}_{2}(\mathrm{t}) \mathrm{P}_{3}(\mathrm{t}) \mathrm{P}_{4}(\mathrm{t}) \mathrm{dt}
$$

Залежності (1) - (4) справедливі для будь-яких законів розподілу напрацювання до відмови елементів і узагальнені на випадок послідовної системи 3 n елементів для експоненціального закону табл. 1.

Як приклад, розглянемо традиційну зубчасту муфту виробу М-3, з прямими внутрішніми і бочкоподібними зовнішніми зубами, при $\mathrm{N}=13235$ кВт; $\mathrm{n}=5250$ об/хв; $\mathrm{z}=60 ; \quad \mathrm{m}=50 \mathrm{Mм} ; \quad \alpha_{\mathrm{w}}=20^{\circ}$; $\mathrm{b}=45 \mathrm{Mм} ; \quad \mathrm{b}_{1}=50 \mathrm{MM} ; \quad \delta_{\Sigma}=5,5 \cdot 10^{-6} \mathrm{MM} / \mathrm{H}$; $\mathrm{R}=3250$ мм; матеріал -високолегована сталь.

$$
\begin{gathered}
\mathrm{T}^{\prime}=\frac{9995 \cdot \mathrm{N}}{\mathrm{n}}=24075 \mathrm{H} \cdot \mathrm{M} ; \\
\mathrm{F}_{\mathrm{n}}=\frac{2 \mathrm{~T}}{\mathrm{mz}^{2} \cos \alpha_{\mathrm{w}}}=2,847 \cdot 10^{3} \mathrm{H} ;
\end{gathered}
$$

$$
\mathrm{F}_{\mathrm{t}}=\mathrm{F}_{\mathrm{n}} \cos \alpha_{\mathrm{w}}=2,675 \cdot 10^{3} \mathrm{H} \text {. }
$$

Максимальне зусилля, що діє на найбільш навантажену пов'язану пару зубів в умовах перекосу осей можна розрахувати:

$$
\begin{aligned}
& \mathrm{F}_{\mathrm{n} \max }(\gamma)=\frac{\pi \mathrm{F}_{\mathrm{m}}}{2 \gamma \cos \alpha_{\mathrm{w}}}+\frac{\psi^{2}}{4 \delta_{\Sigma}} . \\
& \quad\left[\left(\frac{\mathrm{R}}{\cos \alpha_{\mathrm{w}}}-\frac{\mathrm{mz \alpha _{w }}}{2}\right)\left(1-\frac{\sin 2 \gamma}{2 \gamma}\right)+\frac{\mathrm{mzsin}^{2} \gamma}{2 \pi \gamma}\right] .
\end{aligned}
$$

В результаті розрахунку при кутах перекосу осей $\psi=(2,5 ; 5,0 ; 7,5 ; 10,0) \cdot 10^{-3}$ рад [2] показано, що кут в межах якого зуби знаходяться в зачепленні (в межах однієї чверті муфти) будуть рівні відповідно $\gamma=90 ; 65 ; 45 ; 36$ град, а максимальне зусилля $\mathrm{F}_{\mathrm{nmax}}(\gamma)=(3,823 ; 6,545 ; 8,936 ; 11,001) \cdot 10^{3} \mathrm{H}$, це вказує на перевантаженість зубів у 1,34; 2,30; 3,14 і 3,86 рази. Вказане перевантаження викликано тим що в зачепленні одночасно знаходиться частина зубів, а саме: $z=60$ (при $\psi=2,5 \cdot 10^{-3}$ рад) - всі зубів в зачепленні; $z=43$ (при $\psi=5,0 \cdot 10^{-3}$ рад); $z=30$ (при $\psi=7,5 \cdot 10^{-3}$ рад) і $z=24$ (при $\psi=10,0 \cdot 10^{-3}$ рад) однак при даному куті перекосу традиційні зубчасті муфти повністю виходять з ладу. Слід відмітити, що середнє напрацювання муфти до відмови в залежності від кута перекосу буде зменшуватися із 17000 до 6800 годин, а інтенсивність відмов відповідно збільшуватися $35,9 \cdot 10^{-5} 1 /$ ч до $14,71 \cdot 10^{-5} 1 /$ ч. Тобто, збільшення кутів перекосів осей призводить до зменшення кількості зубів муфти що одночасно знаходяться в зачепленні, а це означає, що одна частина зубів буде перевантаженою, а друга недовантаженою, що в свою чергу вказує на те, що ймовірність безвідмовної роботи суднової енергетичної установки безпосередньо залежить від ймовірності безвідмовної роботи зубчастих муфт що входять до іiі складу, проте традиційні зубчасті муфти в умовах розцентровок осей з'єднувальних валів мають незадовільну працездатність, а перецентровка є трудомісткою і дорогою.

Параметри експоненціального розподілу

Таблиця 1

\begin{tabular}{|c|c|c|c|c|}
\hline $\begin{array}{c}\text { Імовірність безвід- } \\
\text { мовної роботи } \mathrm{P}(\mathrm{t})\end{array}$ & $\begin{array}{c}\text { Імовірність } \\
\text { відмови } \mathrm{Q}(\mathrm{t})\end{array}$ & $\begin{array}{c}\text { Частота } \\
\text { відмов } \mathrm{f}(\mathrm{t})\end{array}$ & $\begin{array}{c}\text { Інтенсивність } \\
\text { відмов } \lambda(\mathrm{t})\end{array}$ & $\begin{array}{c}\text { Середнє напрацю- } \\
\text { вання до відмови T }\end{array}$ \\
\hline $\mathrm{e}^{-\sum_{\mathrm{i}=1}^{\mathrm{n}} \lambda_{\mathrm{i}} \mathrm{t}}$ & $1-\mathrm{e}^{-\sum_{\mathrm{i}=1}^{\mathrm{n}} \lambda_{\mathrm{i}} \mathrm{t}}$ & $\sum_{\mathrm{i}=1}^{\mathrm{n}} \lambda_{\mathrm{i}} \mathrm{e}^{-\sum_{\mathrm{i}=1}^{\mathrm{n}} \lambda_{\mathrm{i}} \mathrm{t}}$ & $\sum_{\mathrm{i}=1}^{\mathrm{n}} \lambda_{\mathrm{i}}$ & $\frac{1}{\sum_{\mathrm{i}=1}^{\mathrm{n}} \lambda_{\mathrm{i}}}$ \\
\hline
\end{tabular}


Забезпечити параметри надійності СЕУ можливо шляхом застосування зубчастих муфт підвищеної експлуатаційної ефективності, що складаються із обойми $з$ прямими внутрішніми зубами і втулки 3 зовнішніми зубами зі змінною бочкоподібністю, в межах їх довжини, при цьому змінний радіус бочкоподібності $\mathrm{R}(\varphi)$ зовнішніх зубів знаходяться із виразу [4]

$$
\mathrm{R}(\varphi)=\frac{\mathrm{mz} \cos \alpha_{\mathrm{w}}}{2}\left(\alpha_{\mathrm{w}}+\operatorname{tg} \varphi\right)
$$

де $\mathrm{m}$ - модуль зачеплення; $\mathrm{z}$ - число зубів; $\varphi_{\mathrm{w}}$ - кут зачеплення; $\varphi$ - кут повороту довільно взятої спряженої пари зубів.

Стосовно зубчастої муфти що пропонується, встановлено раніше невідому об'єктивно існуючу властивість зубчастої муфти, працюючої при перекосах осей з'єднувальних валів, яка полягає в тому, що при певному нелінійному законі зміни твірних бічних поверхонь зовнішніх зубів втулки зусилля в процесі навантаження муфти розподіляються рівномірно між всіма спряженими парами зубів. Тобто, вказані зубчасті муфти працюють, практично, як ідеальний шарнір, а отже всі зуби муфти будуть знаходитися в зачепленні в незалежності від кута перекосу осей, а максимальне зусилля буде практично рівним нормальному

$$
F_{n \max }(\gamma)=F_{n}=\text { const, }
$$

а зменшення рівня вібрації і шуму складе приблизно 8-10 дБ.

\section{Висновки}

Підвищення надійності суднових енергетичних установок шляхом усунення негативного впливу розцентровок осей з'єднуються валів суднових агрегатів можливо за рахунок застосування зубчастих муфт підвищеної експлуатаційної ефективності, 3 прямими внутрішніми зубами обойми і зовнішніми зубами зі змінною бочкоподібністю втулки. Вказані муфти практично не чутливі до прекосів осей суднових агрегатів, за рахунок поздовжньої модифікації і наявності між зубами гарантованих бічних та радіальних зазорів.

Застосування цих компенсуючих пристроїв у складі суднових енергетичних установок, які працюють в умовах перекосів осей, дозволить забезпечити передачу ефективної потужності, від головного двигуна судновому валопроводу, через сполучний вузол «муфта-вал-муфта» майже без втрат, що в свою чергу дозволить збільшити безвідмовність плавання судна, знизити витрати на ремонт і експлуатацію, підвищити провозоздатність суден, а також може знизити ймовірність виникнення аварійних ситуацій.

\section{Література}

1. Nobuo, K. Statistical Study on Reliability of Ship Equipment and Safety Management -Reliability Estimation for Failures on Main Engine System by Ship Reliability Database System [Text] / Kiriya Nobuo // Bulletin of the JIME. - 2001. - Vol. 29, No.2 - P. 64-70.

2. Повынение работоспособности машинных агрегатов при перекосах осей соединяемых валов путём применения высокоэффективных зубчатых мyфm [Text]/Alex Popov, Oleg Savenkov, Dmitry Marchenko, Antonina Savenkova // Motrol. Commission of Motorization and Energetics in Agriculture. - LublinRzesow (Poland), 2016. - Vol. 18, Iss. 2. - P. 9-17.

3. Курносенко, Д. В. Основні критерії очінки працездатності суднової енергетичної установки [Текст] / Д. В. Курносенко, I. В. Грииук // Матеріали 10-ї Міжнародної науково-практичної конференції «Сучасні енергетичні установки на транспорті $i$ технології та обладнання для їх обслуговування». Херсон : Херсонська державна морська академія, 2019. - C. 47-49.

4. Пат. № 108010 Україна, F16D 1/00, F16D 1/06 (2006.01), F16D 3/18(2006.01). Зубчаста муфта [Текст] / Попов О. П., Медведовський О. М., Попова Л. О., Савенков О. І. ; Власник Національний університет кораблебудування імені адмірала Макарова. - № а201308624 ; заявл. 09.07.2013 ; опубл 10.03.2015, Бюл. № 5. -5 c.

\section{References}

1. Nobuo, K. Statistical Study on Reliability of Ship Equipment and Safety Management -Reliability Estimation for Failures on Main Engine System by Ship Reliability Database System. Bulletin of the JIME, 2001, vol. 29, no. 2, pp. 64-70.

2. Popov, A., Savenkov, O., Marchenko, D., Savenkova A. Povyshenie rabotosposobnosti mashinnykh agregatov pri perekosakh osei soedinyaemykh valov putem primeneniya vysokoeffektivnykh zubchatykh muft [Improving the performance of machine units in case of misalignment of the axes of the connected shafts by using highly efficient gear couplings]. Motrol. Commission of Motorization and Energetics in Agriculture, Lublin-Rzesow (Poland), 2016, vol. 18, iss. 2, pp. 9-17.

3. Kurnosenko, D. V., Hrytsu, I. V. Osnovni kryteriyi otsinky pratsezdatnosti sudnovoyi enerhe- 
tychnoyi ustanovky [The main criteria for assessing the performance of a ship power plant]. Materialy 10-i Mizhnarodnoi naukovo-praktychnoi konferentsii «Suchasni enerhetychni ustanovky na transporti $i$ tekhnolohii ta obladnannia dlia yikh obsluhovuvannia» - Proceedings of the 10th International Scientific and Practical Conference "Modern power plants in transport and technologies and equipment for their maintenance", Kherson, Khersonska derzhavna morska akademiia Publ., 2019, pp. 47-49.

4. Popov, O. P., Medvedovskyi, O. M., Popova, L. O., Savenkov, O. I. Zubchasta mufta [Toothed clutch]. Patent UA, no. 108010, 2015.

Надійшла до редакції 05.12.2020, розглянута на редколегії 16.02.2021

\section{ПОВЫШЕНИЕ НАДЕЖНОСТИ СУДОВЫХ ЭНЕРГЕТИЧЕСКИХ УСТАНОВОК ПУТЕМ УСТРАНЕНИЯ НЕГАТИВНОГО ВЛИЯНИЯ РАСЦЕНТРОВОК ОСЕЙ СОЕДИНЯЕМЫХ ВАЛОВ}

\section{О. И. Савенков, А. П. Попов, Н. И. Радченко, Ю. Г. Щербак}

Исследовано влияние на работоспособность и надежность судовых энергетических установок перекос осей соединительных валов судовых агрегатов. Рассмотрены причины возникновения расцентровок осей соединительных валов судовых агрегатов и предложена их классификация. Отказы судовых энергетических установок классифицировано по их влиянию на работоспособность установки (по последствиям) по способам их устранения и по характеру и разделены на группы в соответствии с классами. Показано что в процессе эксплуатации, в условиях перекоса осей, традиционные конструкции зубчатых муфт, характеризуются неравномерным распределением усилий между сопряженными парами зубьев, что приводит к их перегрузке и, как следствие, снижению нагрузочной способности, росту величин контактных напряжений, ухудшению условий смазки поверхностей трения зубов, увеличению затрат мощности на трение, снижению коэффициента полезного действия и ухудшение виброакустических характеристик вследствие ударной нагрузки зубов. Рассмотрены способы повышения эффективности работы судовых энергетических установок путем обеспечения параметров надежности главных энергетических установок за счет устранения негативного влияния перекосов осей соединительных валов судовых агрегатов путем применения компенсирующих устройств. Предложено использовать в качестве компенсирующих устройств конструкции зубчатых муфт повышенной эксплуатационной эффективности, которые, в условиях перекоса осей, характеризуются более равномерным распределением усилий между всеми сопряженными парами зубьев чем существующие, то есть работают практически как идеальный шарнир. Касательно предлагаемых зубчатых муфт, установлено ранее неизвестное объективно существующее свойство зубчатой муфты, работающей при перекосах осей соединительных валов, которое заключается в том, что при определенном нелинейном законе изменения образующих боковых поверхностей наружных зубов втулки усилия в процессе погрузки муфты распределяются равномерно между всеми сопряженными парами зубьев. Рассмотрено применение зубчатых муфт повышенной эксплуатационной эффективности в составе судовых энергетических установок и составлены, соответственно, принципиальная и функциональная (структурные) схемы главного судового агрегата с последовательным соединением элементов, с целью оценки воздействия на параметры надежности.

Ключевые слова: судовая энергетическая установка; надежность; расцентровки осей; перекос осей; судовой агрегат; зубчатая муфта.

\section{INCREASING THE STRENGTH OF SHIP POWER PLANT BY ELIMINATING THE NEGATIVE EFFECTS OF THE CENTERING AXES OF THE CONNECTING SHAFTS}

\section{O. Savenkov, A. Popov, M. Radchenko, Y. Shcherbak}

The influence of skew axes of the connecting shafts of marine aggregates on the efficiency and reliability of ship power plants is investigated. The reasons for the occurrence of centerings of axes of connecting shafts of marine aggregates are considered and their classification is offered. Failures of ship power plants are classified according to their impact on the efficiency of the installation (according to the consequences), according to the methods of their elimination, and by their nature and are divided into the groups according to the classes. It is shown that during operation, in the conditions of axial skew, traditional designs of the toothed clutch are characterized by non-uniform distribution of forces between pair of gears, which leads to their overload and, as a consequence, reduced load capacity, increased contact stresses, deterioration of lubrication surfaces of gears, increase in power consumption for friction, reduction of efficiency and deterioration of vibroacoustic characteristics due to shock load of gear. Ways to increase the efficiency of ship power plants by providing parameters of reliability of the main power plants by elim- 
inating the negative impact of the centering axes of the connecting shafts of marine aggregates through the use of compensating devices are considered. It is proposed to use as compensating devices, the design of high-efficiency clutch, which in the conditions of axial skew, are characterized by a more uniform distribution of forces between pair of gears than existing ones, ie work almost as a perfect hinge. Regarding the proposed toothed couplings, a previously unknown objectively existing property of the toothed clutch operating at the skew of the axes of the connecting shafts is established, which is that under a certain nonlinear law changes in the generating side surfaces of the outer teeth evenly between all conjugate pairs of teeth. The use of a high-efficiency clutch in the ship power plants is considered and the basic and functional (structural) scheme of the main marine aggregate with a series connection of elements is made to assess the impact on reliability parameters.

Keywords: ship power plant; reliability; centering axes; skew axes; marine aggregate; toothed clutch.

Савенков Олег Ігорович - асистент, Національний університет кораблебудування імені адмірала Макарова, Миколаїв, Україна.

Попов Олексій Павлович - д-р техн. наук, проф., Національний університет кораблебудування імені адмірала Макарова, Миколаїв, Україна.

Радченко Микола Іванович - д-р техн. наук, проф., Національний університет кораблебудування імені адмірала Макарова, Миколаїв, Україна.

Щербак Юрій Георгійович - канд. техн. наук, доц., Чорноморський Національний університет ім. П. Могили, Україна.

Oleg Savenkov - Lecturer, Admiral Makarov National University of Shipbuilding, Mykolaiv, Ukraine, e-mail: oleg.savenkov@nuos.edu.ua, ORCID: 0000-0002-7165-3995.

Aleksey Popov - Doctor of Technical Science, Professor, Admiral Makarov National University of Shipbuilding, Mykolaiv, Ukraine, e-mail: rmn.nuk@gmail.com, ORCID: 0000-0003-0284-5034.

Mykola Radchenko - Doctor of Technical Science, Professor, Admiral Makarov National University of Shipbuilding, Mykolaiv, Ukraine,

e-mail: nirad50@gmail.com, ORCID: 0000-0001-5796-5370.

Yurii Shcherbak - Candidate of Technical Science $(\mathrm{PhD})$, associate professor, Petro Mohyla Black Sea National University, Mykolayiv, Ukraine, e-mail: butoma-1@mksat.net, ORCID: 0000-0002-0875-6254. 